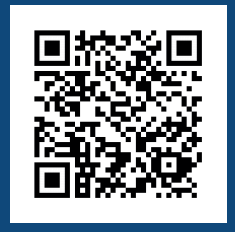

Keywords:

Anatomical discrimination Carbonization process Native species

Historic:

Received 06/04/2018 Accepted 03/09/2018

Correspondence: silvana.ufpr@gmail.com
Rafaela Stange ${ }^{\text {la }}$, Helena Cristina Vieira ${ }^{2 a}$, Polliana D `Angelo Rios ${ }^{1 b}$, Silvana Nisgoski ${ }^{2 b+}$

\section{WOOD AND CHARCOAL ANATOMY OF FOUR MYRTACEAE SPECIES}

STANGE, R.; VIEIRA, H. C.; RIOS, P. D.; NISGOSKI, S. Wood and charcoal anatomy of four myrtaceae species. CERNE, v. 24, n. 3, p. 190-200, 2018.

\section{HIGHLIGHTS}

Anatomical structure of charcoal from four native species of Myrtaceae family;

Some species from studied genera are in list of endangered;

Correct discrimination of charcoal in commerce control;

After carbonization: decrease in vessel diameter and ray dimensions.

\section{ABSTRACT}

Qualitative and quantitative changes in anatomical characteristics of charcoal from Campomanesia xanthocarpa, Eugenia pyriformis, Myrcia retorta and Plinia peruviana were described to provide its correct discrimination and information's to contribute to evaluations in illegal logging. The material came from Planalto Catarinense region, southern Brazil. For each species, three discs at diameter at breast height were collected from three randomly selected trees. All the disks were sectioned to obtain samples in different positions of the trunk (bark, intermediate and pith). Samples were wrapped in aluminum foil and carbonized in a muffle furnace, with a final temperature of $450^{\circ} \mathrm{C}$ and a heating rate of $1.66^{\circ} \mathrm{C} \cdot \mathrm{min}^{-1}$. In species analyzed, growth rings are few distinct, delimitated by fiber regions; solitary vessel and axial parenchyma diffuse or diffuse-in-aggregate is predominant. The wood to charcoal conversion caused variation in the following characteristics: vessel diameters decreased varying from $21.1 \%$ in Myrcia retorta to $33.4 \%$ in Eugenia pyriformis, while the vessel frequency increased with values from $50.7 \%$ to $92.3 \%$ related to the same species; height and width of the rays showed reduction, however, Myrcia retorta presented ruptures in ray cells and dimensions increased; ray frequency increased from $3.9 \%$ in Eugenia pyriformis to $54.1 \%$ in Campomanesia xantocharpa. Qualitative characteristics of wood from studied species remained in charcoal after carbonization at $450^{\circ} \mathrm{C}$, being possible to discriminate the material based on wood anatomy. In charcoal, vessels dimensions and frequency, after ray characteristics can be applied as first step in this Myrtaceae species distinction at forest control. 


\section{INTRODUCTION}

In tropical forests of world, in charcoal production, literature report the use of native species from deforestation regions, and also that there is no selection of cut species. The process impact soil, affects global warming through the production and emission of gases, such as carbon dioxide and methane (Chidumayo and Gumbo, 2013). In Brazil, statistics shows that this scenario is being modified in function of environment legislation and more control in inspection process. In 2016, charcoal manufacture from native forest present a reduction of $31.7 \%$ (IBGE, 2016) and the use of planted species is estimated in $84 \%$ of total consume of country (IBÁ, 2017). On the other hand, data no included in official statistics shows that charcoal production present a high economic and social importance for much family farmers in southern Brazil and, in this case, native species are applied (Bauer et al., 20I5).

In Santa Catarina, Brazil, the Araucaria Forest is composed by 925 species from 439 genera and 116 botanic families. Myrtaceae family is the second in number of species related (Gasper et al., 20l3) and some of them are listed as endangered on Brazilian legislation, for example 5 species from genera Campomanesia, 20 from Eugenia, 10 from Myrcia and 8 from Plinia (MMA, 20I4). A correct identification of species is important in forest control, and as in charcoal qualitative anatomical characteristics remain (Braadbaart and Pole, 2008; Kwon et al., 2009), a database from different species can help in its evaluation.

Changes in cell dimensions after carbonization process are described in literature as a response of anatomical and chemical composition of wood species and also process characteristics (heating rate, final temperature and total time), but qualitative information remains and can be applied in species identification (Nisgoski et al., 20l4; Muñiz et al., 2016; Gasson et al., 2017). In general, tangential diameter of vessel presents reduction and its frequency an increase (Gonçalves et al., 2012, 2016) but are not linear and are related to species characteristics as fiber cell wall and parenchyma distribution (Gonçalves and Scheel-Ybert, 20I6).

Some studies with charcoal from native species are present in literature, but from Myrtaceae family only charcoal from Myrcia bella (Gonçalves et al., 2016) was found. So, considering charcoal production and commerce with native species in southern Brazil, this paper has the objective to evaluate and compare wood and charcoal from four Myrtaceae species, to provide a correct discrimination and contribute to control of illegal logging, by providing information on carbonized wood.

\section{MATERIAL AND METHODS}

Three trees from Campomanesia xanthocarpa Berg, Eugenia pyriformis Cambess, Myrcia retorta Cambess, Plinia peruviana( Poir.) Govaerts, Myrtaceae family, were randomly selected in a natural Forest in Planalto Catarinense region southern Brazil. Botanical material was registered at Lages Herbarium, in University from Santa Catarina State - LUSC (Table I).

TABLE I Data from studied species.

\begin{tabular}{|c|c|c|c|}
\hline $\begin{array}{c}\text { Species - } \\
\text { Register } \\
\text { Herbarium }\end{array}$ & $\begin{array}{l}\text { DBH } \\
(\mathrm{cm})\end{array}$ & Coordinates & $\begin{array}{c}\text { Altitude } \\
\text { (m) }\end{array}$ \\
\hline
\end{tabular}

Campomanesia xanthocarpa Berg

LUSC 6I88 39.5 lat: -27.49703। long: -50.8I053। WGS84 680.0

LUSC 618934.0 lat: -27.483358 long: -50.808750 WGS84 730.0

LUSC 619022.0 lat: -27.483217 long: -50.808783 WGS84 733.0

\begin{tabular}{lccc}
\hline \multicolumn{4}{c}{ Eugenia pyriformis Cambess. } \\
\hline LUSC 6219 & 18.0 lat: -27.489200 long: -50.975007 WGS84 & $*$ \\
LUSC 6220 & 15.0 lat: -27.482667 long: -50.8 II278 WGS84 & 750.9 \\
LUSC 622I & I5.0 lat: -27.48276 I long: -50.8। I5।4 WGS84 & 752.7 \\
\hline \multicolumn{4}{c}{ Myrcia retorta Cambess }
\end{tabular}

LUSC 6252 27.I lat: -27.492825 long: -50.8I2278 WGS84 764.7

LUSC 625317.3 lat: -27.492783 long: -50.812303 WGS84 790.6

LUSC 625410.6 lat: -27.492894 long: -50.8I2364 WGS84 758.4 Plinia peruviana (Poir.) Govaerts

LUSC 632425.8 lat: -27.497356 long: -50.8I0294 WGS84 713.3

LUSC 632526.0 lat: -27.493700 long: -50.803347 WGS84 622.5

LUSC 632622.7 lat: -27.493750 long: -50.802928 WGS84 708.5

* Without register.

For each tree, a disc at diameter at breast height $(\mathrm{DBH})$ was selected for evaluations and a wedge with no defects of each one was cut. Material was divided into three samples oriented in anatomical sections (transversal, radial and tangential), with $2 \times 2 \times 2 \mathrm{~cm}$, named as: near pith, intermediate, and near bark. For wood macroscopic characterization, samples were sanded with 2000 sandpaper.

Wood and charcoal analysis was made in the same samples. After wood evaluation, all samples (moisture content of $12 \pm 1 \%$ ) were wrapped in aluminum foil and carbonized in a muffle furnace, with a final temperature of $450{ }^{\circ} \mathrm{C}$ and a heating rate of $1.66^{\circ} \mathrm{C} \cdot \mathrm{min}^{-1}$ based on Muñiz et al. (20I2a). The carbonized material remained at the final temperature for two hours. Macroscopic description of wood and charcoal was based on images obtained in a Stereomicroscope Discovery VI2 (Zeiss) with software Axio Vision Rel. 4.7. Charcoal details were obtained in a Hitachi TM- 1000 tabletop scanning electron microscope (SEM) directly from the material, without coating. The description of the anatomical elements of 
wood and charcoal samples followed the orientations of the International Association of Wood Anatomists (IAWA, 1989). Number of measurements were adapted on the basis of 30 readings regarding frequency and tangential diameter of the vessels; frequency, height and width of the rays in micrometers.

Data analysis was done in a factorial $2 \times 3$ considering kind of material (wood and charcoal) and different positions in disk (near bark, intermediate, near pith). Differences in dimensions between wood and charcoal were evaluated by Scott-Knott test at $95 \%$ of probability.

\section{RESULTS AND DISCUSSION}

\section{Qualitative description}

\section{Campomanesia xanthocarpha Berg.}

The wood present: Growth rings: few distinct by differences in fiber cell wall. Vessels: diffuse-porous (Figure IA), elliptic and circular vessels, most solitary, radial multiples of 2 present, simple perforate plate, intervessel pits alternate. Axial parenchyma: diffuse in aggregate (Figure IA). Rays: heterogeneous, body ray cells procumbent with rows of square marginal cells; multiseriate predominant, uniseriate present, not storied. Fibers: libriform, non-septate and thickwalled. In charcoal, qualitative characteristic remained. It was possible to observe diffuse-porous, solitary vessel predominant, with more contrast (Figure IB); few distinction of axial parenchyma (Figure IC); heterogeneous rays (Figure ID), uniseriate and multiseriate rays (Figure IE). Intervessel pits alternated more visible (Figure IF).

\section{Eugenia pyriformis Cambess}

The wood present: Growth rings: present, delimitated by fiber regions. Vessels: diffuse-porous, elliptic and circular vessels, most solitary, radial multiples of 2-3 present, simple perforate plate, intervessel pits alternate. Axial parenchyma: in continuous bands (Figure $2 A)$, apotracheal diffuse and diffuse in aggregate. Rays:
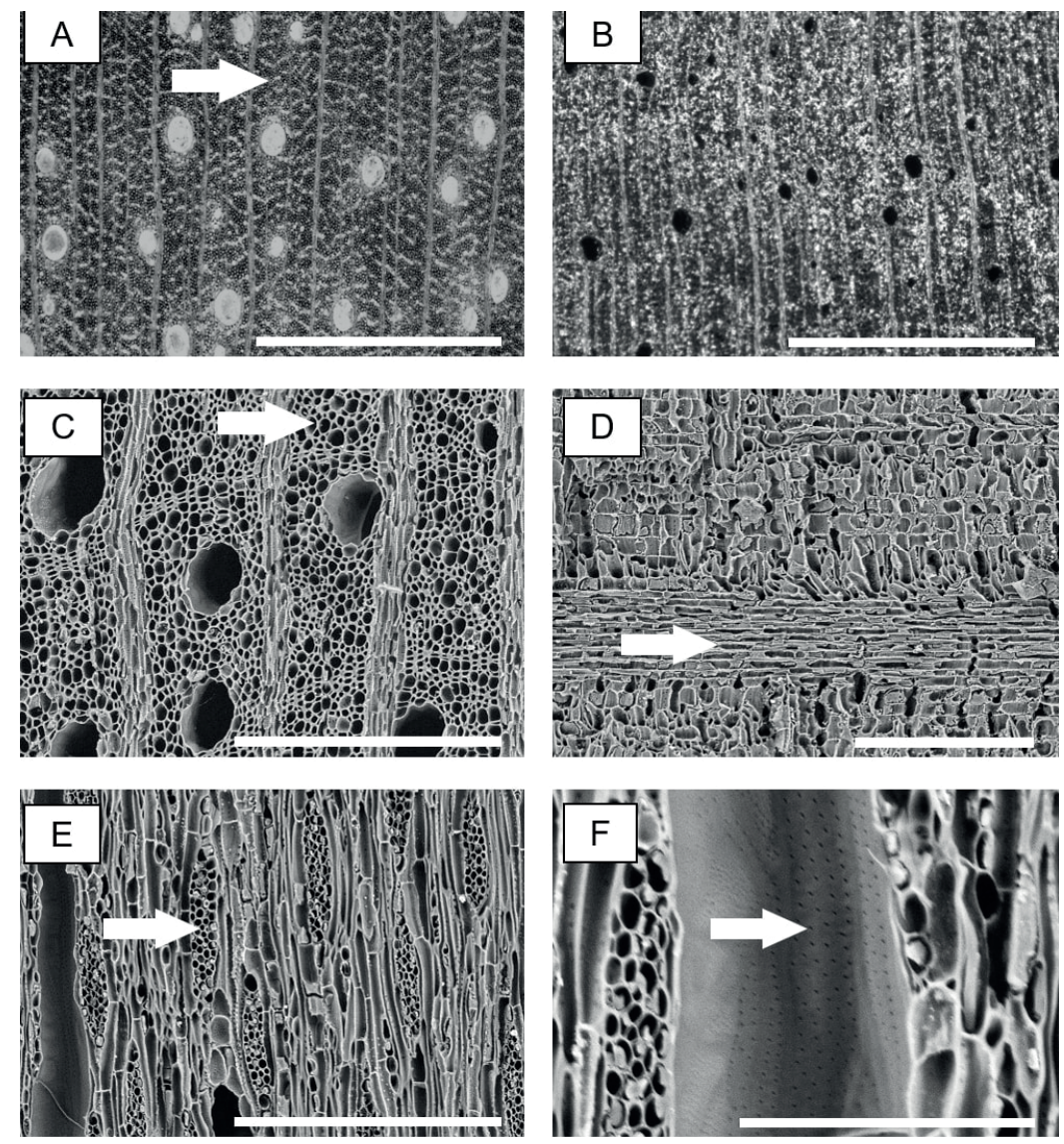

FIGURE I Campomanesia xanthocarpa. Macroscopic image of transversal section from wood (A), arrow indicating axial parenchyma, and charcoal (B). SEM images of charcoal: transversal section (C), arrow indicating axial parenchyma; radial section (D), arrow indicating rays; tangential section $(E)$ arrow shows multiseriate ray; tangential section $(F)$ arrow in alternate intervessel pits. Scale bars: $\mathrm{A}, \mathrm{B}=1000 \mu \mathrm{m} ; \mathrm{C}, \mathrm{D}, \mathrm{E}=300 \mu \mathrm{m} ; \mathrm{F}=100 \mu \mathrm{m}$. 

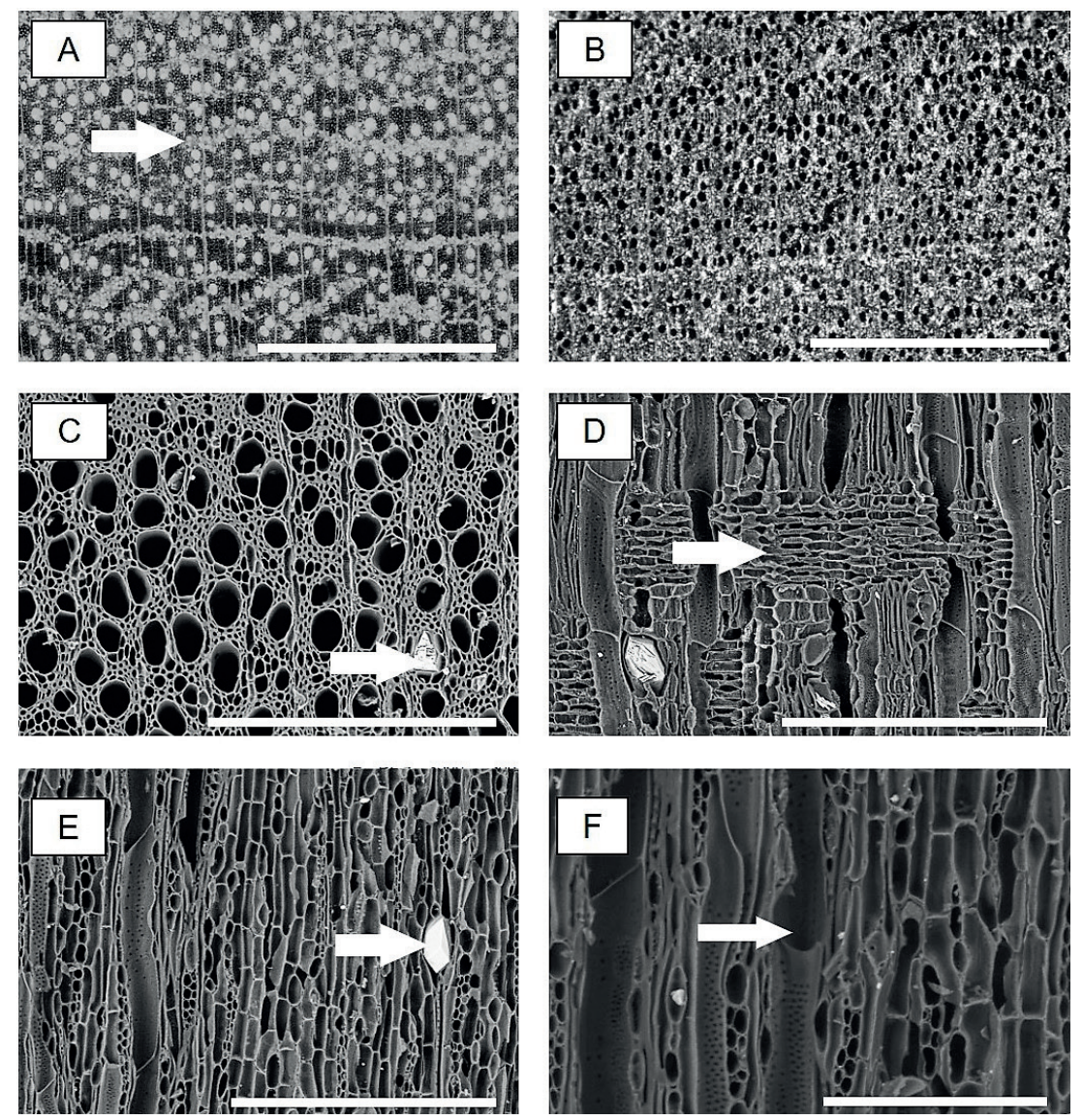

FIGURE 2 Eugenia pyriformis. Macroscopic image of transversal section from wood (A), arrow indicating axial parenchyma, and charcoal (B). SEM images of charcoal: transversal section (C), arrow indicating crystal in parenchyma cell; radial section (D) arrow indicating heterogeneous ray; tangential section $(E)$ arrow demonstrates crystal in ray cell; tangential section $(F)$ arrow shows simple perforate plate. Scale bar: A, B $=1000 \mu \mathrm{m} ; \mathrm{C}, \mathrm{D}, \mathrm{E}=300 \mu \mathrm{m} ; \mathrm{F}=100 \mu \mathrm{m}$.

heterogeneous, body ray cells procumbent with rows of upright and/or square marginal cells; uniseriate and multiseriate, not storied. Fibers: libriform, nonseptate and thick-walled. In charcoal, its qualitative characteristics are the same: Vessels: diffuse-porous (Figure 2B), solitary predominant, radial multiples of 2-3 present (Figure 2C). Axial parenchyma in bands can be observed with some contrast. Rays: heterogeneous (Figure 2D), uniseriate and multiseriate, crystals present in ray cells (Figure $2 \mathrm{E}$ ). Simple perforate plate more visible in charcoal (Figure 2F).

\section{Myrcia retorta Cambess}

The wood present: Growth rings: few distinct marked by fibers regions. Vessels: diffuse-porous (Figure $3 A$ ), rounded, solitary predominant, simple perforate plate, intervessel pits alternate. Axial parenchyma: apotracheal diffuse and diffuse in aggregate, scanty paratracheal. Rays: heterogeneous, body ray cells procumbent with rows of upright and/or square marginal cells; multiseriate, not storied. Fibers: libriform, nonseptate and thin-walled. In charcoal, some changes were verified after carbonization process. In transversal section it was possible to verify cracks in rays, probably in function of thin-walled fibers. Vessel present retraction (Figure $3 B, C)$; few contrast in axial parenchyma; heterogeneous rays (Figure 3D) and multisseriate rays (Figure $3 \mathrm{E}$ ) are more evident in charcoal. Simple perforate plate is also visible in radial section (Figure 3F).

\section{Plinia peruviana (Poir.) Govaerts}

The wood present: Growth rings: few distinct marked by fiber regions. Vessels: diffuse-porous (Figure $4 A$ ), rounded, exclusively solitary, simple perforate plate, intervessel pits alternate. Axial parenchyma: apotracheal diffuse and diffuse in aggregate, scanty paratracheal. Rays: heterogeneous, body ray cells procumbent with rows of upright and/or square marginal cells; multiseriate predominant, uniseriate present, not storied. Fibers: with distinct bordered pits, non-septate and thick-walled. In 

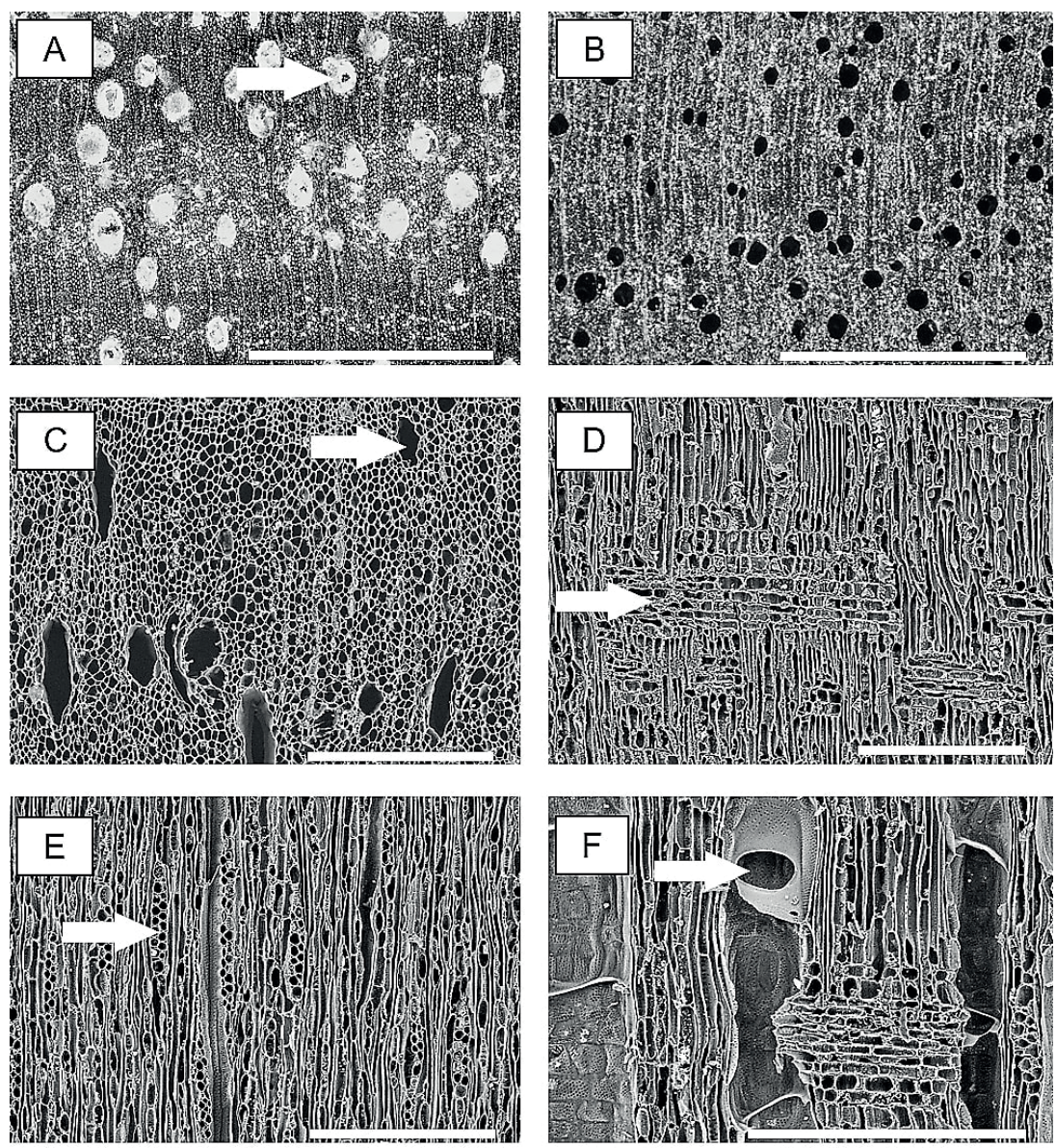

FIGURE 3 Myrcia retorta. Macroscopic image of transversal section from wood (A), arrow indicating rounded vessel, and charcoal (B). SEM images of charcoal: transversal section (C) arrow illustrating changes in vessel diameter; radial section (D) arrow showing heterogeneous ray; tangential section $(E)$, arrow in multiseriate ray; radial section $(F)$, arrow in simple perforate plate. Scale bar: $\mathrm{A}, \mathrm{B},=1000 \mu \mathrm{m} ; \mathrm{C}, \mathrm{D}, \mathrm{E}, \mathrm{F}=300 \mu \mathrm{m}$;

charcoal, qualitative characteristics present the same distribution: vessels in diffuse-porous (Figure 4B), solitary predominant (Figure 4C); few contrast in axial parenchyma; heterogeneous rays (Figure 4D) and multiseriate rays (Figure 4E) more visible. Simple perforation plate also visible in tangential section (Figure 4F).

\section{Quantitative characteristics - variation in cell dimensions}

\section{Tangential diameter and frequency of vessel}

Means of vessel diameter (Table 2) shows a decrease in all positions (near bark, intermediate, near pith) after carbonization process. Only for intermediate position of Campomanesia xanthocarpa alterations were not statistically significant. For all studied species and positions, vessel frequency increased after carbonization process (Table 2). Changes in values in different positions were influence by species and material (wood or charcoal).
Evaluating sample position in Campomanesia xanthocarpa wood it was verified a significant difference in vessel diameter between region near bark and near pith related to intermediate position, i.e. vessels were bigger in extremities. In charcoal, the same difference was observed, but the comportment was inverse, in intermediate region the reduction in vessel diameter was approximately $5 \%$ while in region near bark and near pith alterations were of $29-30 \%$. Vessel diameter for wood and charcoal are similar to reports in literature for wood: in samples collected in Rio Grande do Sul, Santos and Marchiori (20II) related a vessel diameter varying from 17.5 to $141.3 \mu \mathrm{m}$, and Soffiatti et al. (2016) verified mean values of approximately $109 \mu \mathrm{m}$ (52.48-139.79) in trees collected in Paraná state. In wood, region near bark present more vessel frequency in comparison to intermediate region and near pith. In charcoal all positions were distinct, and intermediate region present smallest vessel frequency. Increase in frequency was 

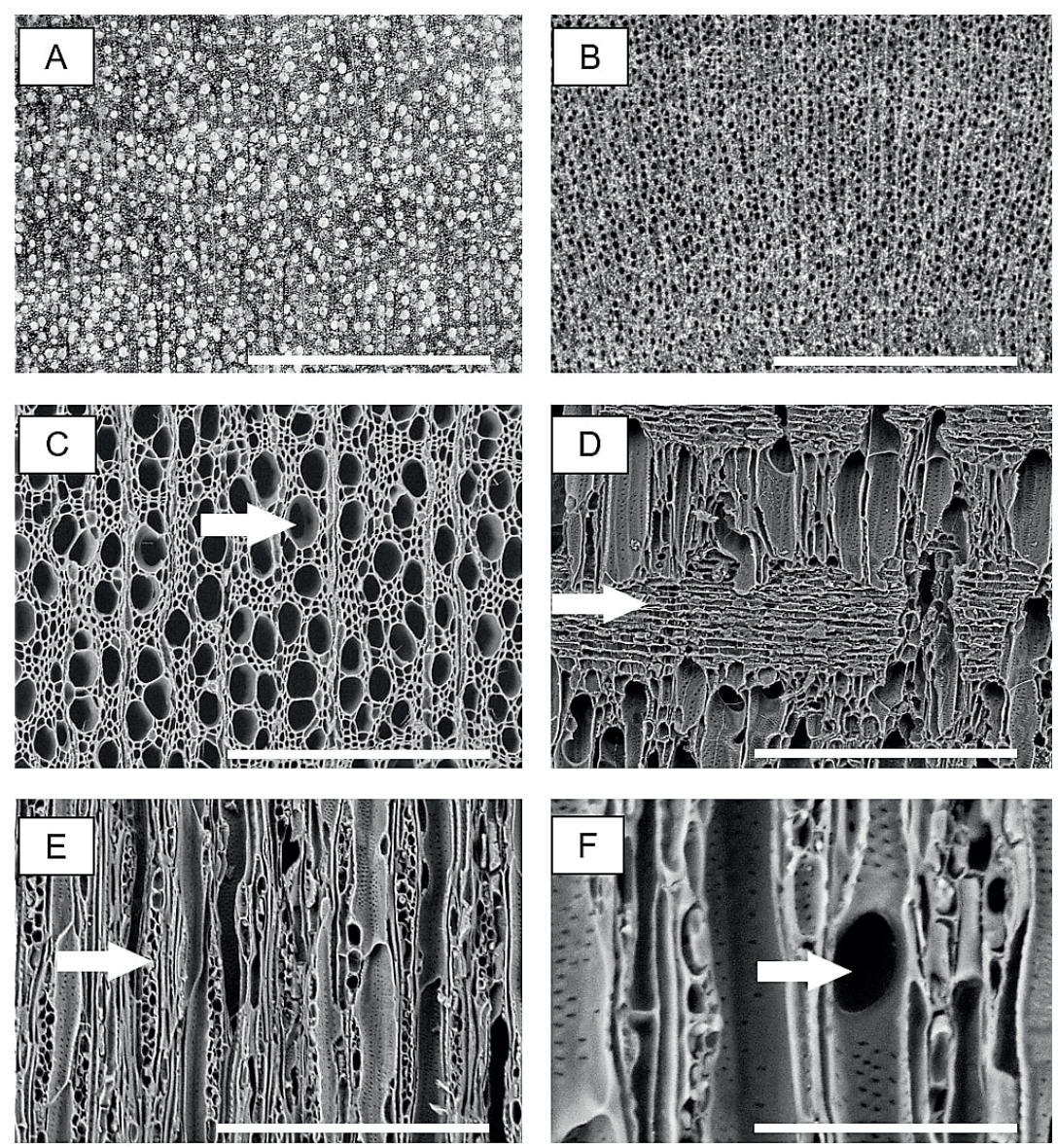

FIGURE 4 Plinia peruviana. Macroscopic image of transversal section from wood (A) and charcoal (B). SEM images of charcoal: transversal section $(C)$, arrow indicate solitary vessel; radial section (D), arrow illustrating heterogeneous rays; tangential section $(E, F)$ arrows showing multiseriate rays $(E)$ and simple perforation plate $(F)$. Scale bar: $A, B=1000$ $\mu \mathrm{m} ; \mathrm{C}, \mathrm{D}, \mathrm{E}=300 \mu \mathrm{m} ; \mathrm{F}=100 \mu \mathrm{m}$.

TABLE 2 Mean tangential diameter and frequency of vessel (standard deviation) of studied species.

\begin{tabular}{|c|c|c|c|c|}
\hline Species & Material & Near bark & Intermediate & Near pith \\
\hline \multicolumn{5}{|c|}{ Tangential diameter $(\mu \mathrm{m})$} \\
\hline \multirow{2}{*}{ Campomanesia xanthocarpa } & Wood & $94.92 \mathrm{Aa}(19.74)$ & $81.79 \mathrm{Ab}(25.83)$ & $90.09 \mathrm{Aa}(24.59)$ \\
\hline & Charcoal & $67.17 \mathrm{Bb}(17.75)$ & $77.32 \mathrm{Aa}(23.10)$ & 62.7I Bb (16.37) \\
\hline \multirow{2}{*}{ Eugenia pyriformis* } & Wood & $34.72 \mathrm{Aa}(5.3 \mathrm{I})$ & $32.34 \mathrm{Ab}(5.25)$ & $30.50 \mathrm{Ac}(5.83)$ \\
\hline & Charcoal & $23.74 \mathrm{Ba}(5.30)$ & $22.03 \mathrm{Bb}(4.93)$ & $19.34 \mathrm{Bc}(4.96)$ \\
\hline \multirow{2}{*}{ Myrcia retorta* } & Wood & $82.72 \mathrm{Aa}(20.66)$ & $75.65 \mathrm{Ab}(19.24)$ & $75.75 \mathrm{Ab}(16.70)$ \\
\hline & Charcoal & $65.17 \mathrm{Ba}(17.62)$ & $57.57 \mathrm{Bb}(15.03)$ & $61.98 \mathrm{Ba}(16.28)$ \\
\hline \multirow{2}{*}{ Plinia peruviana* } & Wood & $30.34 \mathrm{Ab}(5.2 \mathrm{I})$ & $32.70 \mathrm{Aa}(4.92)$ & $28.89 \mathrm{Ab}(5.66)$ \\
\hline & Charcoal & $23.25 \mathrm{Ba}(5.20)$ & $21.10 \mathrm{Bb}(4.29)$ & $20.44 \mathrm{Bb}(3.75)$ \\
\hline \multicolumn{5}{|c|}{ Vessel frequency $\left(\mathrm{n} \cdot \mathrm{mm}^{-2}\right)$} \\
\hline \multirow{2}{*}{ Campomanesia xanthocarpa } & Wood & $10.24 \mathrm{Ba}(3.73)$ & $8.46 \mathrm{Bb}(3.56)$ & $8.76 \mathrm{Bb}(2.67)$ \\
\hline & Charcoal & 16.47 Aa (5.23) & $12.53 \mathrm{Ac}(4.52)$ & I5.08 Ab (4.3I) \\
\hline \multirow{2}{*}{ Eugenia pyriformis } & Wood & $124.16 \mathrm{Bb}(21.95)$ & $132.89 \mathrm{Bb}(18.0 \mathrm{I})$ & $174.10 \mathrm{Ba}(40.04)$ \\
\hline & Charcoal & $250.87 \mathrm{Ab}(55.62)$ & $250.36 \mathrm{Ab}(32.57)$ & $326.62 \mathrm{Aa}(90.77)$ \\
\hline \multirow{2}{*}{ Myrcia retorta } & Wood & I4.06 Bb (3.37) & I3. I4 Bb (3.76) & $21.97 \mathrm{Ba}(8.7 \mathrm{I})$ \\
\hline & Charcoal & $23.24 \mathrm{Aa}(7.3 \mathrm{I})$ & $23.14 \mathrm{Aa}(7.19)$ & $24.3 \mathrm{I} \mathrm{Aa}(5.02)$ \\
\hline \multirow{2}{*}{ Plinia peruviana* } & Wood & $177.18 \mathrm{Bb}(49.77)$ & $162.87 \mathrm{Bc}(3 \mathrm{I} .48)$ & 190.82 Ba (34.35) \\
\hline & Charcoal & $329.42 \mathrm{Aa}(74.48)$ & $300.34 \mathrm{Ab}(60.01)$ & $347.82 \mathrm{Aa}(78.40)$ \\
\hline
\end{tabular}

For each species, equal letter in means do not present statistical differences by Scott-Knott test at $95 \%$ of probability. Capital letter in column refers to material (wood/charcoal) and small letters are related to position on disk (near bark, intermediate, near pith). *Species where interaction between material and position was not significant at $95 \%$ of probability. 
observed after carbonization process in all positions, varying from $48 \%$ in intermediate region, to $72 \%$ near pith. Frequency is similar to wood reported by Santos and Marchiori (20II) in material from Rio Grande do Sul, varying from $12-25$ vessels $\cdot \mathrm{mm}^{-2}$.

For Eugenia pyriformis, all positions presented decrease in vessel diameter after carbonization process, varying from approximately $32 \%$ in region near bark and intermediate, and $37 \%$ in region near pith. Also species shows a gradual reduction from bark to pith in vessel diameter of wood and charcoal. In wood of other species from genus Eugenia, Santos and Marchiori (201 I) reported mean values varying from 25 to $61 \mu \mathrm{m}$ in samples from Rio Grande do Sul, and Sonsin et al. (2014) related mean values of $56 \mu \mathrm{m}$ in Eugenia bimarginata from Cerrado. For wood and charcoal region near pith present the great number of vessel $\mathrm{mm}^{-2}$, and also the increase in number after carbonization process was observed in all positions, with values from approximately $88 \%$, in intermediate region and near pith, until $102 \%$ near bark. In two species from Cerrado, Sonsin et al. (2014) verified mean frequency of vessel of 70 (Eugenia bimarginata) and 124 (Eugenia rigida), and Santos and Marchiori (20I I) related in species from Atlantic Forest values from $20-143$ vessels $\cdot \mathrm{mm}^{-2}$.

In Myrcia retorta wood, region near bark present vessels with bigger diameter, different from intermediate and near pith which are equal. In charcoal, diverse comportment was observed, decrease in dimension do not follow values of wood, intermediate region present smallest vessels and a reduction of $24 \%$, region near bark (decrease of $21 \%$ ) are similar to region near pith (decrease of $18 \%$ ). Behavior of this species was similar to literature for other species. For wood of Myrcia bella from Cerrado, Sonsin et al. (2014) verified mean values of $64 \mu \mathrm{m}$ and for charcoal, from the same material, Gonçalves et al. (2016) reported a mean value of $56 \mu \mathrm{m}$, varying from 39-80 $\mu \mathrm{m}$. Evaluating differences between position in wood, region near pith present more vessels than intermediate and near bark. In charcoal it was not observed difference in vessel frequency in function of sample position. An increase in vessel frequency was verified after carbonization for all samples, and varied from $11 \%$, in region near pith, to $76 \%$ in intermediate region. For Myrcia bella wood from Cerrado, Sonsin et al. (2014) related mean frequency of 37 vessels $\cdot \mathrm{mm}^{-2}$, and in charcoal, Gonçalves et al. (2016) reported a mean value of 44 vessels $\mathrm{mm}^{-2}$, varying from $32-60 \mu \mathrm{m}$, being similar to observed in this study for other species.
Observing Plinia peruviana wood, intermediate region present vessels with larger diameter, while region near bark and pith are similar. After carbonization process all samples showed reduction in vessel diameter, a reduction of $23 \%, 36 \%$ and $29 \%$ was verified for regions near bark, intermediate and near pith, respectively. Comparing only charcoal dimensions, region near bark is different from others and present vessels with bigger diameter. Small vessel diameter in genus Plinia is also reported for other species, for example, Plinia rivularis present values from 32.5-70 $\mu \mathrm{m}$ and Plinia trunciflora from 17.5-38.7 (Santos and Marchiori, 20I I). All positions of wood are different in number of vessel, and fewer vessels were observed in intermediate region. In charcoal, intermediate region is different from near bark and near pith. In all samples an increase after carbonization process in vessel frequency was verified with little variation between positions: $86 \%$ in region near bark, $84 \%$ in intermediate region, and $82 \%$ near pith. In wood from other species from genus Plinia, a frequency of 75-162 was reported in literature (Santos and Marchiori, 20I4).

Reduction in vessel diameter after carbonization process is the result of material contraction and must be influenced by species characteristics, and process conditions as heating rate, the difference in regimes and the duration of the process (Nisgoski et al., 2014). In carbonization process, chemical components of cell wall are degraded, and in consequence, the volume occupied by charcoal in a furnace is less than wood volume inside. This fact characterizes contraction of carbonized material and reduction in vessel diameter (Pereira et al., 2016). Higher extractives contents associated with lower crystallinity and lower crystallite size can accelerate the degradation process and reduce wood thermal stability (Poletto et al., 2012). Also fiber cell wall and kind of axial parenchyma can influence dimensional changes in vessel diameter (Muñiz et al. 2012a, 2016; Pereira et al., 2016).

In this study, evaluating mean reduction of vessel diameter by species, it was observed a great decrease in Eugenia pyriformis (33.4\%), in sequence, Plinia peruviana (29.4\%), Campomanesia xanthocarpa (21.7\%) and Myrcia retorta (21.1\%). Some studies in native species report reduction in vessel diameter after carbonization process, for example, in Cerrado species Gonçalves et al. (20I2) related decrease in $70 \%$ of evaluated material; in five wood similar to angelim, Muñiz et al. (2016) verified changes in all species studied; and in five species from Santa Catarina state, Araucaria Forest, Carvalho et al. 
(2017) reported decrease in tangential diameter of vessels in all samples.

Related to variations of vessel frequency by species after carbonization process, it was observed a great increase in Eugenia pyriformis (92.3\%), in sequence, Plinia peruviana (84.0\%), Campomanesia xanthocarpa (60.3\%) and Myrcia retorta (50.7\%). In all species it was observed increase in frequency and decrease in vessel diameter (Table 2) after carbonization and is the result of cell contraction in function of temperature. Changes in vessel frequency after carbonization process were commented in other studies: Nisgoski et al. (2014) evaluating samples of Ocotea porosa in different final temperatures in carbonization process observed no direct relation between decrease in vessel diameter and increase in vessel frequency. Other studies with forest species (Muñiz et al., 20l2b; Nisgoski et al., 20l2), angelim species (Muñiz et al., 2016) and Anacardiaceae species (Gonçalves and Scheel-Ybert, 2016) also showed the influence of species characteristics in changes in vessel frequency, as thickness of fiber wall and disposition of parenchyma cells.

Ray height and width

In most samples it was observed changes in ray height (Table 3). A reduction was present in Campomanesia xanthocarpa, Eugenia pyriformis and Plinia peruviana, and an increase in ray height occurs in Myrcia retorta. Mean value of ray width shows different comportment between position and species and also after carbonization process (Table 3). Differences in species can be related to percentage of multiseriate and uniseriate rays.

In ray height, in Campomanesia xanthocarpa wood, it was not observed differences between positions in direction pith to bark. In charcoal, region near bark present ray with the tallest dimensions. Decrease in ray height varied from I I\% (near bark) to 18\% (intermediate and near pith). Means results in wood are similar to values reported in samples from Atlantic Forest by Santos and Marchiori (20II) which related a mean ray height of 277 $\mu \mathrm{m}$ (140-570), and Soffiatti et al. (2016) who verified mean value of approximately $246.7 \mu \mathrm{m}$ (5I.35-480.86). In wood and charcoal it is possible to notice an increase in ray width from pith to bark. After carbonization, changes occurred in intermediate and region near bark, with decrease in ray width of $6 \%$ and $12 \%$, respectively. In region near pith $5 \%$ of reduction was verified, with no statistical differences. Mean values of wood are greater than observed in tress from Araucaria Forest in Paraná state, which varied from 5.7 to 41.8 , with mean of 26.3 $\mu \mathrm{m}$ described by Soffiatti et al. (20I6).

In Eugenia pyriformis wood and charcoal, ray height is similar in region near bark and intermediate portion, being greater than near pith. In all positions a decrease in dimension after carbonization process was observed with some different change, varying from 17\% (near bark) to $20 \%$ (near pith), being $18 \%$ in intermediate region. Different species of Eugenia from Rio Grande do Sul, described in literature present ray with height varying from $92-1100 \mu \mathrm{m}$, showing a great difference (Santos and Marchiori, 20I I). Some differences in positions were verified for wood and charcoal related to ray width. In wood, region near pith presented the smallest ray width and is statistically diverse from other positions. In charcoal, region near bark present the biggest dimension and is different from regions intermediate and near pith. Charcoal showed and decrease in ray width of $30 \%$ in region near bark, of $34 \%$ in intermediate position, and of $29 \%$ in region near pith.

In the species Myrcia retorta wood there is no difference between samples position, and in charcoal region near pith shows smallest rays, statistically diverse from region near bark and intermediate. Samples present diverse results from other species, after carbonization process an increase in ray height in all positions was observed, varying from $16 \%$ near pith to $34 \%$ in intermediate region. These results are related to ruptures in rays that were the result of expansion of cells walls. Ruptures in rays are also reported in Quercus sp. (Kim and Hanna, 2006), in some eucalyptus species (Gonçalves et al., 2014) and eucalyptus clones (Pereira et al., 2016). In wood, values are smallest than from Myrcia hatschbachii which present mean ray height of approximately $418 \mu \mathrm{m}$, varying from 172-899 $\mu \mathrm{m}$ (Soffiatti et al., 2016). In wood, ray width presented some differences in region bark, and for charcoal it was not observed variations in positions from pith to bark. All samples showed an increase in ray width after carbonization process, and changes of more than $50 \%$. In wood, values of studied species are smallest than from Myrcia hatschbachii which present mean ray width of approximately $22 \mu \mathrm{m}$ (Soffiatti et al., 2016).

For Plinia peruviana wood samples from region near bark and intermediate present biggest rays. In charcoal a non linear variation was observed, region near pith present smallest rays, it increased to intermediate position and decreased in region near bark. After carbonization process a decrease in ray height was verified in region near bark $(17 \%)$ and pith (8\%), on the other hand, intermediate position resulted in no significant statistically changes, with 
TABLE 3 Mean ray height and width (standard deviation) of studied species.

\begin{tabular}{|c|c|c|c|c|}
\hline Species & Material & Near bark & Intermediate & Near pith \\
\hline \multicolumn{5}{|c|}{ Ray height $(\mu \mathrm{m})$} \\
\hline \multirow{2}{*}{ Campomanesia xanthocarpa* } & Wood & $245.54 \mathrm{Aa}(54.12)$ & $248.18 \mathrm{Aa}(57.06)$ & $243.80 \mathrm{Aa}(64.68)$ \\
\hline & Charcoal & $217.89 \mathrm{Ba}(46.67)$ & $204.45 \mathrm{Bb}(58.13)$ & $200.74 \mathrm{Bb}(42.52)$ \\
\hline \multirow{2}{*}{ Eugenia pyriformis* } & Wood & $168.79 \mathrm{Aa}(43.14)$ & I $64.99 \mathrm{Aa}(44.7 \mathrm{I})$ & I5I.9| Ab (46.36) \\
\hline & Charcoal & I $39.98 \mathrm{Ba}(37.74)$ & I35.9| Ba (36.45) & $121.93 \mathrm{Bb}(40.5 \mathrm{I})$ \\
\hline \multirow{2}{*}{ Myrcia retorta } & Wood & $167.65 \mathrm{Ba}(55.53)$ & I59.84 Ba (55.42) & $159.83 \mathrm{Ba}(52.25)$ \\
\hline & Charcoal & $206.66 \mathrm{Aa}(43.8 \mathrm{I})$ & $213.97 \mathrm{Aa}(46.30)$ & I $85.85 \mathrm{Ab}(42.45)$ \\
\hline \multirow{2}{*}{ Plinia peruviana* } & Wood & $\mathrm{I} 77.3 \mathrm{I} \mathrm{Aa}(48.10)$ & I $74.76 \mathrm{Aa}(54.33)$ & I5I.5। Ab (37.98) \\
\hline & Charcoal & $148.12 \mathrm{Bb}(37.44)$ & I $63.79 \mathrm{Aa}(45.03)$ & I38.7| Bb (31. II) \\
\hline \multicolumn{5}{|c|}{ Ray width $(\mu \mathrm{m})$} \\
\hline \multirow{2}{*}{ Campomanesia xanthocarpa* } & Wood & $39.98 \mathrm{Aa}(6.48)$ & $33.6 \mathrm{I} \mathrm{Ab} \mathrm{(7.69)}$ & $30.59 \mathrm{Ac}(6.44)$ \\
\hline & Charcoal & $35.35 \mathrm{Ba}(6.68)$ & $31.45 \mathrm{Bb}(6.49)$ & $29.12 \mathrm{Ac}(6.42)$ \\
\hline \multirow{2}{*}{ Eugenia pyriformis* } & Wood & I6.16 Aa (3.39) & I5.76 Aa (3.26) & $14.60 \mathrm{Ab}(2.54)$ \\
\hline & Charcoal & I I.37 Ba (3.08) & $10.44 \mathrm{Bb}(1.91)$ & $10.39 \mathrm{Bb}(2.30)$ \\
\hline \multirow{2}{*}{ Myrcia retorta* } & Wood & $12.21 \mathrm{Ba}(2.93)$ & $\mathrm{II} .14 \mathrm{Bb}(2.52)$ & I I.48 Bb (2.62) \\
\hline & Charcoal & I8.39 Aa (3.54) & I7.8I Aa (3.97) & I8.20 Aa (3.24) \\
\hline \multirow{2}{*}{ Plinia peruviana* } & Wood & I8.62 Aa (4.66) & $18.66 \mathrm{Aa}(5.1 \mathrm{I})$ & $\mathrm{I} 6.54 \mathrm{Ab}(4.85)$ \\
\hline & Charcoal & I $3.88 \mathrm{Ba}(3.40)$ & $12.29 \mathrm{Bb}(1.93)$ & $11.16 \mathrm{Bc}(2.68)$ \\
\hline
\end{tabular}

For each species, equal letter in means do not present statistical differences by Scott-Knott test at $95 \%$ of probability. Capital letter in column refers to material (wood/charcoal) and small letters are related to position on disk (near bark, intermediate, near pith). *Species where interaction between material and position was not significant at $95 \%$ of probability.

approximately $6 \%$ of reduction. The influence of sample position in ray width was observed only in region near pith, in wood. In charcoal, all material was different. After carbonization process, a decrease in all samples occurred. Changes varied from $26 \%$ (region near bark) to $34 \%$ (intermediate region).

In this study, evaluating mean changes of ray height by species, it was observed an increase of $24.3 \%$ in Myrcia retorta, and a decrease, in sequence, for Eugenia pyriformis (18.3\%), Campomanesia xanthocarpa (I5.7\%) and Plinia peruviana (10.0\%). Other studies with native species also report different comportment, in the same carbonization process of this study, related to thickness of fiber wall (Muñiz et al., 20I2a), to characteristics of ray cell composition (homogeneous or heterogeneous) and comments about specific variations intra and inter individuals (Gonçalves et al., 20I2).

For example, a reduction in ray height after carbonization process was observed in Stryphnodendron polyphyllum and Tapirira guianensis (Gonçalves et al., 2012), Enterolobium schomburgkii (Muñiz et al., 2012a), Ficus citrifolia, Hieronyma laxiflora, Sapium glandulatum (Nisgoski et al., 2015) and Diplotropis purpurea (Muñiz et al., 2016). On the other hand, an increase in ray height, is related in Cedrelinga catenaeformis (Muñiz et al., 20I2a), in Ocotea porosa (Nisgoski et al., 20।4), and no statistical changes were verified in Hymenolobium petraeum, Parkia pendula, Vatairea guianensis and Vatairea paraensis (Muñiz et al., 2016).
In this study, evaluating mean changes of ray width by species, it was observed an increase of $56.3 \%$ in Myrcia retorta, and a similar decrease for Eugenia pyriformis and Plinia peruviana (30.7\%), and few reductions in Campomanesia xanthocarpa (7.6\%). Decrease in ray width was also reported in Enterolobium schomburgkii (Muñiz et al., 20I2a). The same behavior was related by Gonçalves et al. (2012) in Stryphnodendron polyphyllum, Croton grandiflora and Vochysia tucanorum. On the other hand, an increase in ray width was also observed in Cedrelinga catenaeformis (Muñiz et al., 2012a) and can be related to chemical changes in substances stored at parenchyma cells which can expand and result in gas components.

Variations in ray width by species can explain different comportment. It was commented by Kim and Hanna (2006), evaluating Quercus variabilis, that in uniseriate ray its morphological characteristics remained and cell presented small separations, instead of multisseriate rays showed disintegration in cell wall and honeycombed wood was verified with increase in carbonization temperature.

Ray frequency

After carbonization different behavior was observed and influence of position and species was verified (Table 4). Variations in position of Campomanesia xanthocarpa wood was only present between region near pith and other positions. In charcoal, all positions showed difference in ray frequency. After carbonization 
process an increase in ray frequency was observed for all positions, varying from approximately $52 \%$, in region near pith and near bark, to $58 \%$ in intermediate region. In wood, Santos and Marchiori (20II) verified a mean ray frequency of $13 \mathrm{~mm}^{-1}$, varying from $10-15$ evaluating wood from Rio Grande do Sul.

In Eugenia pyriformis wood, region near bark present less vessels by millimeter being different from other positions. In charcoal it was observed more rays in region near pith, being diverse from other samples. Changes in ray frequency after carbonization occurred only in position near bark, with an increase of $6 \%$.

For Myrcia retorta positions from pith to bark present no influence in ray frequency in wood and charcoal. Some increase in frequency was observed for region near bark (10\%) and intermediate region (7\%). Gonçalves et al. (2016) reported in charcoal frequency of 17, varying from 13-21 rays by millimeter in Myrcia bella, in wood Sonsin et al. (2014) verified a mean value of $13 \mathrm{~mm}^{-1}$.

Influence of position in samples from Plinia peruviana was only observed in intermediate region of wood material, which resulted in less frequency and is different from others. In charcoal production, an increase in ray frequency was verified for all positions, varying from approximately $29 \%$ in region near pith to $57 \%$ in intermediate region.

In this study, evaluating changes in ray frequency by species, it was observed an increase of $54.1 \%$ in Campomanesia xanthocarpa, $41.3 \%$ in Plinia peruviana, $5.9 \%$ in Myrcia retorta and $3.9 \%$ in Eugenia pyriformis. These variations are the results of different contraction and homogenization of cell wall. Ávila et al. (2017) comments that these variations can be explained by mass loss and wood contraction in function of carbonization process, but also intraspecific and ecological trends can be involved.

\section{CONCLUSION}

The wood to charcoal conversion caused variation in the following characteristics: decrease in vessel diameter; increase in vessel frequency; decrease in ray height and width in Campomanesia xanthocarpa, Eugenia pyriformis and Plinia peruviana and opposite behavior in Myrcia retorta; increase in vessel frequency in all species. The species Myrcia retorta presented ruptures in ray cells.

Qualitative characteristics of wood from studied species remained in charcoal after carbonization at $450^{\circ} \mathrm{C}$, being possible to discriminate the material based on wood anatomy. In charcoal, vessels dimensions and frequency, after ray characteristics can be applied as first step in this Myrtaceae species distinction at forest control.

\section{REFERENCES}

ÁVILA, A.; GIONGO, C.; SCHEEL-YBERT, R. Anatomia do lenho carbonizado de 10 espécies nativas da planície costeira do Rio Grande do Sul - subsídio a pesquisas arqueobotânicas e paleoecológicas. Cadernos do LEPAARQ (UFPEL), v. I4, n. 27, p. 482-5। I, 2017.

BAUER, E.; ELIAS, L.P.; ARAÚJO, L.A.; TORESAN, L.; DOROW, R.; GOMEZ, C.U.; RECH, T.D. A produção de carvão vegetal na agricultura familiar do Sul do Brasil: retrato de uma realidade escondida. Revista PerCursos, v. 16, n. 30, p. 99-I2I, $20 \mid 5$.

BRAADBAART, F; POOLE, I. Morphological, chemical and physical changes during charcoalification of wood and its relevance to archaeological contexts. Journal of Archaeological Science, v.35, p. 2434-2445, 2008.

CARVALHO, A.F.; BRAND, M.A.; NISGOSKI, S.; MUÑIZ, G.I.B.; FRIEDERICHS, G.; KUSTER, L.C.; SANTOS, T.S. Anatomia do carvão oriundo de cinco espécies comercializadas no estado de Santa Catarina. Ciência da Madeira, v. 8, n. 3, p. 158-167, 2017.

CHIDUMAYO, E.N.; GUMBO, D.J. The environmental impacts of charcoal production in tropical ecosystems of the world: A synthesis. Energy for Sustainable Development, v. 17, p. 86-94, 2013.

TABLE 4 Ray frequency $\left(\mathrm{n} \cdot \mathrm{mm}^{-1}\right)$ (standard deviation) of studied species.

\begin{tabular}{|c|c|c|c|c|}
\hline Species & Material & Near bark & Intermediate & Near pith \\
\hline \multirow{2}{*}{ Campomanesia xanthocarpa* } & Wood & $6.97 \mathrm{Bb}(1.93)$ & $7.29 \mathrm{Bb}(2.30)$ & $8.17 \mathrm{Ba}(2.5 \mathrm{I})$ \\
\hline & Charcoal & $10.59 \mathrm{Ac}(1.84)$ & II.54 Ab (I.9I) & I2.42 Aa (2.36) \\
\hline \multirow{2}{*}{ Eugenia pyriformis* } & Wood & 9.78 Bb (2.2I) & I0.7I Aa (2.34) & I0.9। Aa (2.24) \\
\hline & Charcoal & I0.40 Ab (I.89) & $10.76 \mathrm{Ab}(2.70)$ & I I.42 Aa (2.02) \\
\hline \multirow{2}{*}{ Myrcia retorta* } & Wood & $14.89 \mathrm{Ba}(2.29)$ & $15.10 \mathrm{Ba}(3.19)$ & I5.63 Aa (3.48) \\
\hline & Charcoal & I6.3I Aa (2.86) & I6. I $2 \mathrm{Aa}(2.70)$ & I5.87 Aa (2.78) \\
\hline \multirow{2}{*}{ Plinia peruviana } & Wood & $10.83 \mathrm{Ba}(2.6 \mathrm{I})$ & $9.60 \mathrm{Bb}(2.59)$ & II.2I Ba (2.34) \\
\hline & Charcoal & $14.92 \mathrm{Aa}(2.18)$ & I5.04 Aa (I.63) & I4.5। Aa (3.35) \\
\hline
\end{tabular}

For each species, equal letter in means do not present statistical differences by Scott-Knott test at $95 \%$ of probability. Capital letter in column refers to material (wood/charcoal) and small letters are related to position on disk (near bark, intermediate, near pith). *Species where interaction between material and position was not significant at $95 \%$ of probability. 
GASPER, A. L.; SEVEGNANI, L.; VIBRANS, A. C.; MARCOS SOBRAL, M.; UHLMANN, A.; LINGNER, D. V.; RIGON JÚNIOR, M. J.; VERDI, M.; SANTOS, A. S.; DREVECK S.; KORTE, A. Inventário florístico florestal de Santa Catarina: espécies da Floresta Ombrófila Mista. Rodriguésia, v. 64, n. 2, p. 20I-2I0, 2013.

GASSON, P.; CARTWRIGHT, C.; DIAS LEME, C.L. Anatomical changes to the wood of Croton sonderianus (Euphorbiaceae) when charred at different temperatures. IAWA Journal, v.38, n.I, p.II7-123, 2017.

GONCALVES, T.A.P.; BALLARIN, A.W.; NISGOSKI, S.; MUÑIZ, G.I.B. A contribution to the identification of charcoal origin in Brazil I - Anatomical characterization of Corymbia and Eucalyptus. Maderas. Ciencia yTecnologia, v.16, n. 30, p. 323-336, 2014.

GONÇALVES, T.A.P.; MARCATI, C.R.; SCHEEL-YBERT, R. The effect of carbonization on wood structure of Dalbergia violaceae, Stryphnodendron polyphyllum, Tapirira guianensis, Vochysia tucanorum and Pouteria torta from the Brazilian Cerrado. IAWA Journal, v. 33, n. I, p. 73-90, 2012.

GONÇALVES, T.A.P.; NISGOSKI, S.; OLIVEIRA, J.S.; MARCATI, C.R.; BALLARIN, A.W.; MUÑIZ, G.I.B. A contribution to the identification of charcoal origin in Brazil II - Macroscopic characterization of Cerrado species. Anais da Academia Brasileira de Ciências, v. 88, n. 2, p. 1045-1054, 2016.

GONÇALVES, T.A.P.; SCHEEL-YBERT, R. Charcoal anatomy of Brazilian species. I. Anacardiaceae. Anais da Academia Brasileira de Ciências, v. 88, n. 3, p. I7II-|725, 2016.

IAWA. List of microscopic features for hardwood identification. IAWA Bulletin, v. 10, n. 3, p. 219-332, 1989.

IBÁ. Indústria Brasileira de Árvores. Relatório 2017. IBÁ: São Paulo, 2017. 80p.

IBGE. Instituto Brasileiro de Geografia e Estatística. Produção da Extração Vegetal e da Silvicultura. Rio de Janeiro: IBGE, v. 3I, 54p. 2016.

KIM, N.H.; HANNA, R.B. Morphological characteristics Quercus variabilis charcoal prepared at different temperatures. Wood Science and Technology, v.40, n.5, p.392-40I, 2006.

KWON, S.M.; KIM, N.H.; CHA, D.S. An investigation on the transition characteristics of the wood cell walls during carbonization. Wood Science and Technology, v.43, n.56, p.487-498, 2009.

MMA. Lista Nacional Oficial de Espécies da Flora Ameaçadas de Extinção. Ministério do Meio Ambiente. Portaria MMA n 443, 2014.

MUÑIZ, G.I.B.; CARNEIRO, M.E.;BATISTA, F.R.R.;SCHARDOSIN, F.Z.S.; NISGOSKI, S. Wood and charcoal identification of five species from the miscellaneous group known in Brazil as "angelim" by near-ir and wood anatomy. Maderas. Ciencia y Tecnología, v. I8, n. 3, p. 505 - 522, 2016.
MUÑIZ, G.I.B.; NISGOSKI, S.; FRANÇA, R.F.; SCHARDOSIN, F.Z. Comparative anatomy of wood and charcoal of Cedrelinga catenaeformis Ducke and Enterolobium schomburgkii Benth. for identification purposes. Scientia Forestalis, v.40, n. 94, p. 291-297, 2012a.

MUÑIZ, G.I.B.; NISGOSKI, S.; SCHARDOSIN, F.Z.; FRANÇA, R.F. Anatomia do carvão de espécies florestais. Cerne, v. I8, n. 3, p. 47I-477, 20I2b.

NISGOSKI, S.; MUÑIZ, G.I.B.; BATISTA, F.R.R.; MÖLLEKEN, R.E. Influence of carbonization temperature on the anatomical characteristics of Ocotea porosa (Nees \& Mart. Ex Nees) L. Barroso. Wood Science and Technology, v.48, p. 30I-309, 2014.

NISGOSKI, S.; MUÑIZ, G.I.B.; FRANÇA, R.F.; BATISTA, F. R. Anatomia do lenho carbonizado de Copaifera cf.langsdorfii Desf. E Dipteryx odorata(Aubl.) Wild. Ciência da Madeira, v. 3, n. 2, p. 66-79, 2012.

NISGOSKI, S.; MUÑIZ, G.I.B.; MORRONE, S.R.; SCHARDOSIN, F.Z.; FRANÇA, R.F. NIR and anatomy of wood and charcoal from Moraceae and Euphorbiaceae species. Ciência da Madeira, v. 6, n. 3, p. I83-190, 2015.

PEREIRA, B.L.C. CARVALHO, A.M.M.L.; OliVEIRA, A. C. O.; SANTOS, L.C.S.; CARNEIRO, A.C.O.; MAGALHÃES, M. A. Efeito da carbonização da madeira na estrutura anatômica e densidade do carvão vegetal de Eucalyptus. Ciência Florestal, v. 26, n. 2, p.545-557, 2016.

POLETTO, M.; ZATTERA, A.J.; FORTE, M.M.C.; SANTANA, R.M.C. Thermal decomposition of wood: Influence of wood components and cellulose crystallite size. Bioresource Technology, v. 109, p. 148-153b, 2012.

SANTOS, S.R.; MARCHIORI, J.N.C. Madeiras do Rio Grande do Sul: descrição microscópica de 34 Mirtáceas nativas. Vol. 4, Anaterra, Santa Maria: 20I I, 80p.

SOFFIATTI, P.; BOEGER, M.R.T.; NISGOSKI, S.; KAUAI, F. Wood anatomical traits of the Araucaria Forest, Southern Brazil. Bosque, v. 37, n. I, p. 21-3I, 2016.

SONSIN, J.O.; GASSON, P.; MACHADO, S.R.; CAUM, C.; MARCATI, C.R. Atlas da diversidade de madeiras do Cerrado paulista. Botucatu: FEPAF, 20I4. 423p. 